\title{
Problems of meat market in terms of ensuring world's food security
}

\author{
Lyudmila Kopteva ${ }^{1}$, Irina Romanova ${ }^{1}$, Svetlana Kulakova ${ }^{2, *}$ \\ ${ }^{1}$ Saint-Petrsburg State University of Aerospase Instrumentation, Bolshaya Morskaia str. 67, 190000, \\ Saint-Petersburg, Russia \\ ${ }^{2}$ Chelyabinsk state University, Kostanay branch, Kashirin Brothers, st., 129, Chelyabinsk, 454001, \\ Russia
}

\begin{abstract}
The present paper focuses on key problems and specifics of ensuring food security and on state of agro-industrial complexes in different countries of the world. The authors defined the main aspects of state support for agriculture in advanced foreign economies and specified the challenges of food security ensuring. Agriculture is such an industry that brings prosperity to those who can work efficiently and make right decisions under high uncertainty, which may imply unsteady weather conditions, market environment, various production risks. Successful development of agriculture requires the ability to forecast and prevent unfavorable situations. In all countries, the main objective of agricultural production is to fully meet population's demand for food using its own resources for manufacturing necessary food products. However, some countries do not have their own resources for agriculture, so they have to import finished products and raw materials for food production from other countries. For today, ensuring food security for all countries of the world is one of the most urgent problems of the mankind. Since the United Nations (the $\mathrm{UN}$ ) was created, the international community has been paying close attention to the shortage of food. The issues of customs tariff regulation, plant and animal health care, administrative barriers - these are the priority tasks demanding systemic approaches, the fulfillment of which will stimulate the breakthrough in agriculture.
\end{abstract}

\section{Introduction}

Agriculture is one of the oldest branches of national economy, which currently is the main industry accountable for food security of the world's population.

In the terms of requirements of food security, N. I. Semenova and S. P. Utyatsky believe that "each country should possess domestic resources for manufacturing essential food products. Nevertheless, different geographical location of world's countries entails their inequality and does not allow some countries to develop agriculture. This makes those countries import not only finished products, but also raw materials for their production" [1].

The term "food security" was firstly mentioned at the World Food Conference held in Rome in 1974, organized by the FAO after the 3-times growth of world prices for grain in

\footnotetext{
* Corresponding author: angela-1309.m@yandex.ru
} 
1972-1974. The concept of food security was described at the same conference in 1996. The term is interpreted as follows: "Food security implies the ensuring for all people of permanent physical and economic access to safe and nutritious food of the amount sufficient to satisfy their needs and preferences in food, of the volumes necessary for an active healthy life". [2]

The aim of the study is to define and describe the problems of meat market and world's food security control.

The following research methods were used while completing the present work: monographic, computational-and-constructive, economic-and-mathematical, analytical, abstract-and-logical, grouping techniques, graphic, etc.

The methodological foundation of the study is the graphic, logical and information analysis. The authors used theoretical and empirical approaches to consider the problem under study.

A. I. Altukhov, G. I. Makin and M. A. Babkov define food security as "the ability of a government to guarantee the satisfaction of people's needs and ensure its proper functioning" [3].

S. S. Dzasarov introduced the following definition in his studies: "Food security is the ability of the government to provide current and emergency needs with food using its own production resources" [4].

Many authors state in their works that ensuring food security is the most vital national priority for all countries of the world [5-17].

In many countries, such as the USA, France, Germany, and others, the level of food self-provisioning in terms of basic food products is $100 \%$ and higher [18].

V.G. Larionov notes: "All countries of the world provide financial support to national agriculture, as this industry has always been and will be subsidized. The amount of state support provided to agriculture by Western countries proves that in advanced economies the principle of reliance on domestic production prevails.

Therefore, the country's food security can be ensured only by taking the integrated approach. Moreover, the basic components of food security must be enshrined at the statutory level.

The Food Security Law was adopted in all developed countries: in Germany, France, Sweden, the USA, and also in China, Belarus, etc.

In the USA, the country's food complex is one of the most protected ones. For these purposes, special regulations were adopted aimed at ensuring the stable food supply through supporting domestic agriculture and preserving natural resources".

N.N. Semenova believes that "the current global challenges of food security are the most solid arguments for state financial support for the agricultural sector of the world economy and also are the main tasks to fulfill for the governments of all countries.

For example, in Western Europe, governments appropriate averagely $\$ 300$ per hectare to support their agriculture, in Japan - \$473, in the USA - \$324, in Russia - \$36” [19].

Over the past century, climate has undergone significant changes: average annual increase in the temperature ranges from $0.3{ }^{\circ} \mathrm{C}$ to $0.6{ }^{\circ} \mathrm{C}$. The analysis of this phenomenon allows predicting the temperature growth by $1.5-4.5{ }^{\circ} \mathrm{C}$, which will globally affect agricultural production, livestock and poultry farming, and this in turn will threaten food security. Climate change can reduce global food production and raise prices for food.

By 2030, agriculture is forecasted to endure a decrease in real income in many large regions due to climate warming. The hardest situation threatens to Africa and South Asia, where the reduction of real incomes in relation to their general decrease in the world can be exceeded by 4-10 times. Due to the onset of drought, grain yield in southern Africa will decrease by $47 \%$, in North America - by $15 \%$, in Asia and South America - by $3-10 \%$, while in Russia it will increase by more than $10 \%$ [20]. 


\section{Analysis}

Ensuring food security of the population is considered the most complex and comprehensive task for all countries of the world. The main factors influencing the global food market are shown in Figure 1:

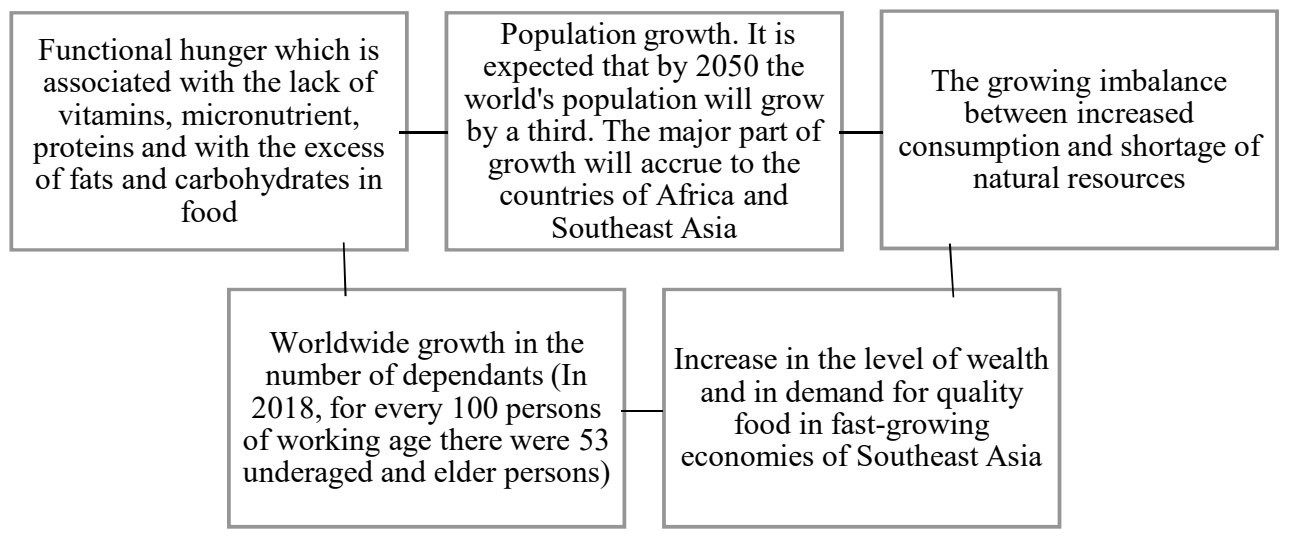

Fig. 1. The main factors influencing the global food market.

Based on the foregoing, it can be stated that the problems of lack of food for the world's population are truly the most relevant today, so that food can be attributed to the most important world's strategic resource, that requires the allocation of the necessary state support.

Agricultural producers themselves also indicate the need for state participation in the form of regulation and support. According to the results of a survey conducted among representatives of agricultural organizations by the consulting company Deloitte, TOP-3 problems of the agricultural sector is annually compiled, which is shown in Figure 2.

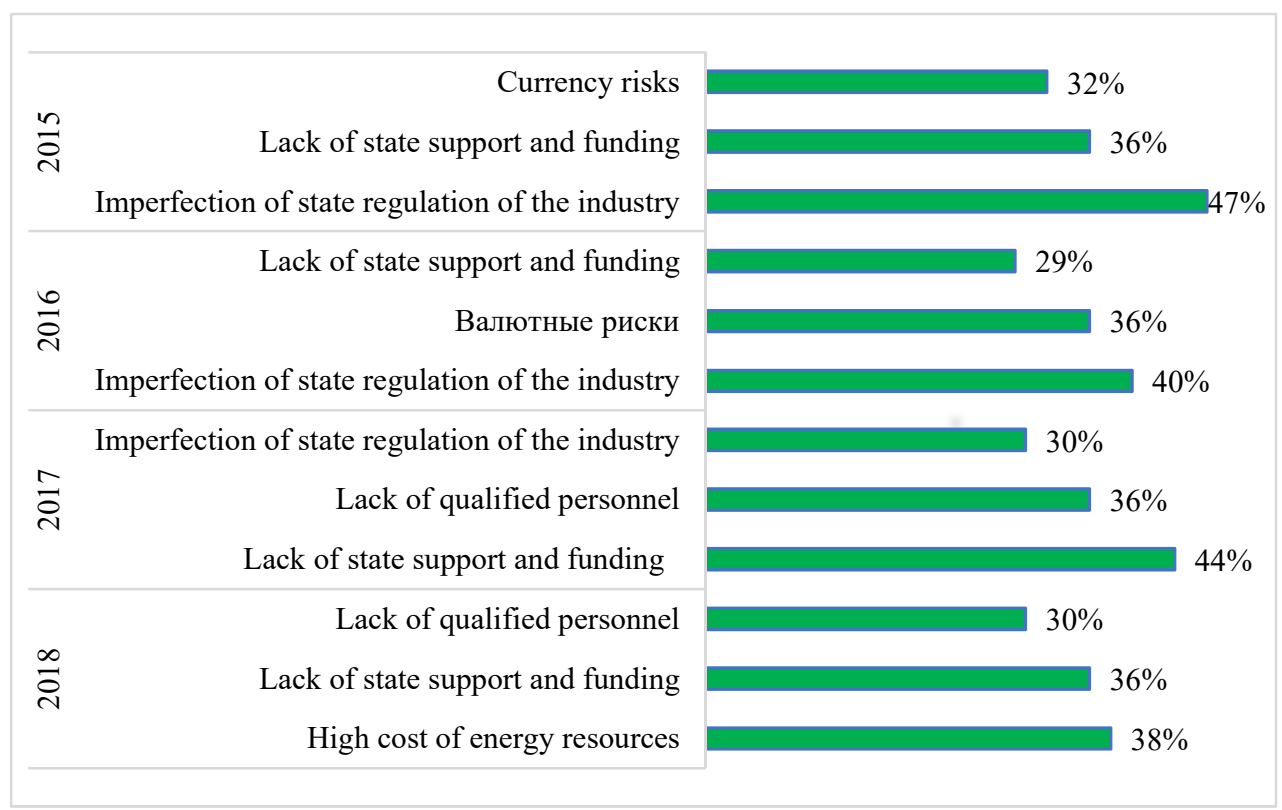

Fig. 2. TOP 3 problems of agricultural complex (Source: compiled by the author according to the source [21]). 
The imperfection of state regulation and the lack of state support rank first positions among the major problems of the agricultural complex. This fact confirms that the efficient performance of the agricultural complex is impossible without a high-quality mechanism of interaction with a government.

The negative experience of the 90s demonstrates how badly uncontrolled import affects the state of agricultural production. The agricultural sector of the Russian economy was almost completely destroyed as a result of reforms and the redistribution of property. The survived remnants of the agricultural business were literally swept away by a wave of cheap imported food.

However, many scientists considered the import of goods as a potential threat to the country's food security. For example, D. Ricardo assumed that state's dependence on foreign products creates the direct threat to the sovereignty of this state [22]. C. B. Bychkova believed that food security can exist only in case of partial or complete termination of importing foreign goods into the territory of the state [23].

A continuous struggle about the rules of import is permanently running. The interests of domestic producers are obviously opposite to the interests of foreign exporters. At the same time, the latter often resort to various frauds to gain more profit.

Therefore, systematic adjustment of customs and tariff regulation is needed with taking into account of market trends. When quoting, it is necessary to take into account not only all types of raw meat and meat products, but also the import of live poultry, pigs and cows. Belgium, where a special committee weekly adjusts export-import, is a good example. The effectiveness of state support in Belgium expressed in the form of grants and subsidies is evidenced by the fact that import of pork fell by $15 \%$ due to state subsidizing the domestic production of pork products.

Production of beef is expected to remain at a high level in 2020 and perhaps in 2021, before there will be many tangible reductions in livestock numbers outside feeding sites. The expansion of the meat cow population, which made the running for markets over the past four years, has also ended. Heifers are no longer held in the breeding herd to expand. Instead, there is an increase in the percentage of heifers fattened: it ranged from $38 \%$ to $40 \%$ in the second half of 2019 , which indicates that the herd is no longer growing.

In addition, due to climatic, geopolitical, and other problems, many countries face difficulties in providing food. Russia also faced some of these problems presented in Figure 3.

One of the challenges in 2019 was the elimination of beef cows. Cattle feed prices are expected to remain unchanged in 2020 compared with the previous two years, which may lead to increased livestock and beef production. The resolution of the trade dispute between the United States and China will enable increasing the supply of pork from the United States to China, which will lead to higher prices for all proteins. Another unexpected movement in the market is the change in global trade flows of animal proteins. Since a large part of beef from Australia and New Zealand goes to China, this causes a decrease in the amount of beef coming to the United States, which results in a growing demand for locally produced beef and leads to higher prices. It is expected that this situation will not be swiftly resolved and will become an interesting trend of market development in 2020. 


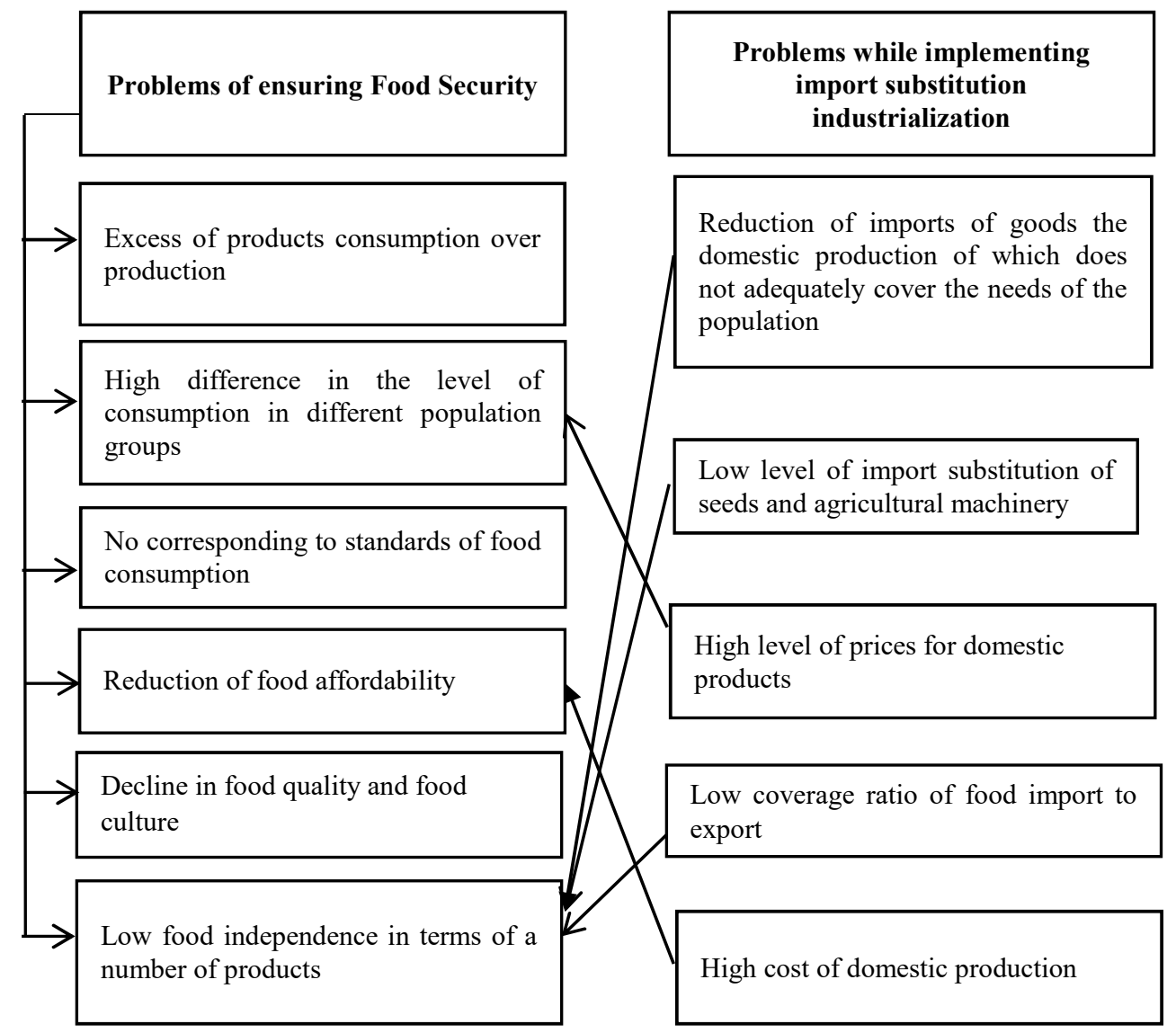

Fig. 3. Problems of ensuring food security and implementing import substitution industrialization.

\section{Prices}

Import prices for agricultural products, uncertainty in Argentina and the unstable Chinese beef market are just three of the whole set of problems that beef producers in the United States faced in the end of 2019. That is what RaboResearch's latest fourth-quarter beef report from Rabobank says. Growing demand in China has multiplied beef imports from Australia and New Zealand.

The report says that they expected the markets of the USA, Australia and New Zealand to continue their competition until 2020. After the prices for imported beef raised, in the United States prices jumped and reached their maximum in 2019. This price pressure forced American fast food restaurants to search for domestic beef supplies, which has led to higher domestic prices for beef in the United States. The increase in slaughtering operations was balanced by the decrease in carcass weight, which was largely due to the difficult weather conditions in the United States.

In addition, exceptionally strong basic levels encouraged hedgers (exchange traders with the goal of executing operations at the stock exchange to protect themselves from the risk of price changes) in putting additional pressure on the cattle market during the most part of the year. Many experts expect the USA to end 2019 with a large number of fattened cattle. However, there is an unusually large share of fattened heifers that are expected to limit carcass weights in 2020. 
The change of government in Argentina entailed the uncertainty in the Argentinean beef market. The instability is caused by the lack of sectoral policies in agriculture and an the increase in export tariffs for beef, just like it was under the previous government. However, high prices and good profit margins for processors can offset any increase in export tariffs. China gives accreditation to more factories to enter the Chinese market due to the high demand for imported protein. 22 factories were approved in Brazil, and 8 in Argentina. In addition, South Africa was admitted to the Chinese market again, and several factories throughout Europe were also approved to supply their products to China. However, the situation on the global beef market will stay tense.

\section{Export}

Total Australian beef exports continued outperforming the one of 2018: for example, exports to China for October nearly doubled compared to 2018.

It is safe to say that Australia is facing extraordinary demand for their beef. In October, China imported 30,724 tons of Australian beef. This is 93 percent higher than in October 2018, and 169 percent higher than averagely within five years.

China has purchased $9-14 \%$ of Australian beef exports for the past five years, and now it is Australia's main target market for cattle meat. However, China purchases a lot of beef from other suppliers too.

Australian beef exports to China are shown in Figure 4.

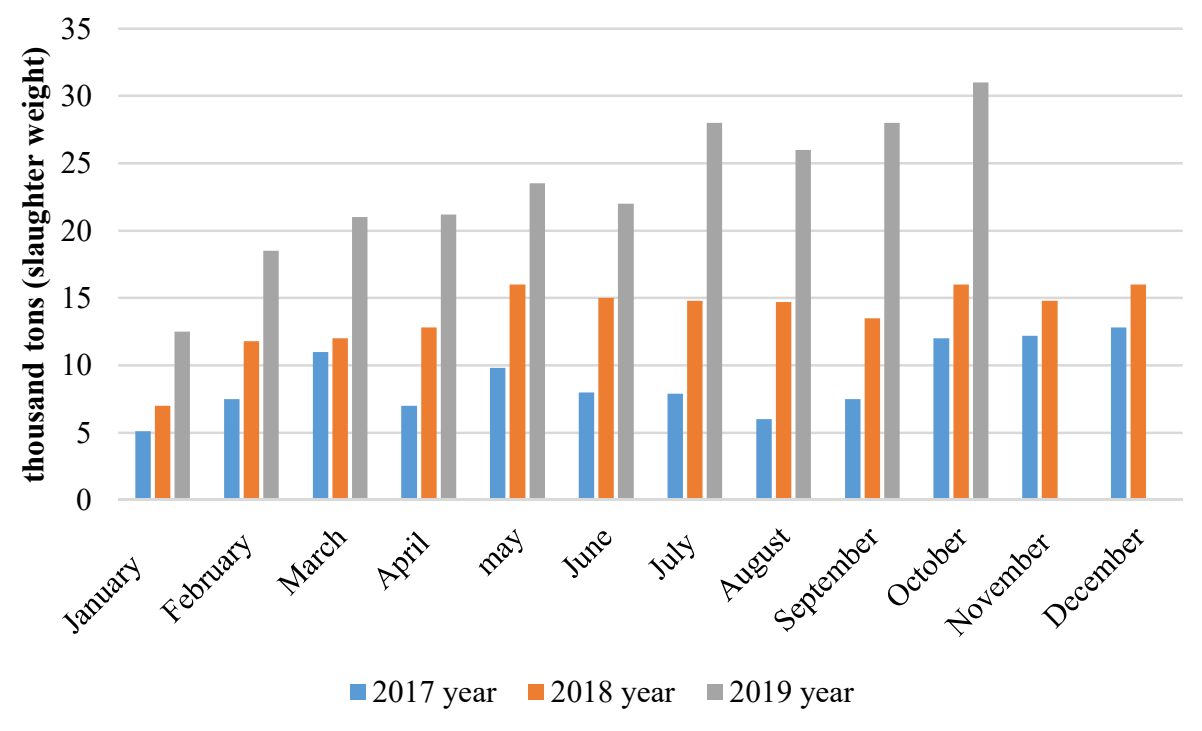

Fig. 4. Beef exports to China from Australia for 2017-2019, thousand tons.

Steiner Consulting recently reported that from September 2018 to September 2019, beef exports from New Zealand to China grew by $70 \%$, and from Uruguay by $20 \%$.

Significant international demand is expected to stimulate the growth of beef exports, while the forecast for beef exports will reach 11.5 million tons in 2020, i.e. by 2019 the growth will be $4 \%$. Increased demand for beef in Asia, driven by declining pork production, will be a key factor of inducing this growth.

The positive influence of Chinese demand on prices continued and intensified while coming to November. There are few prospects for increasing global stocks of beef. A herd of cattle needs to take some time to grow. Recently, in the markets of the USA and Asia, 
there has been a sharp jump in beef purchases due to the increase in its price. Higher China's demand for beef means higher prices. The increase in export prices for beef is finally reflected in livestock production prices. The cost of livestock in Australia has already risen sharply in recent weeks, and experts are confident that this growth will continue.

In January-October 2019, China bought all Brazilian beef, which caused the historically high growth of prices. The Chinese imports of Brazilian meat grew by $23.6 \%$ compared to the same period in 2018, as the Abrafrigo meat processing association reports.

Demand of China is increasingly affecting the supply of beef from Brazil, which has led to an increase in livestock prices in the country to a record high. Chinese demand for imported meat increased, since the outbreak of African swine influenza reduced the number of pigs in the country and led to a shortage of animal protein in the market.

Wholesale prices for beef in the Greater Sao Paulo area have reached a record level, which affects consumer prices. Prices for rose $36.4 \%$ (up to 14.69 rials per kilogram) in Sao Paulo, which is the largest consumer market.

"Meat prices will continue rising, and this will be a problem for consumers," said Andre Braz, an economist at the Getulio Vargas Foundation of a Brazilian university. "When beef rises in price, the price of other meat also rises ... it's a matter of replacement," he said.

\section{Import}

China aims to import more meat from Brazil. For this purpose, they licensed 24 additional beef factories for export since the beginning of 2019 even though only 16 enterprises were allowed to export meat to China in January 2019.

The total export of Brazilian beef in January-October amounted to 1.5 million tons, which is $11 \%$ higher than in 2018 ; exports to China grew by $23.6 \%$ and amounted to 320,000 tons over the same period.

\section{Discussion}

Brazilian Minister of International trade Marcos Troyo said that bilateral trade between Brazil and China was expected to reach 105-110 billion US dollars in 2019. According to statistics from the Brazilian government, last year, bilateral trade between these countries amounted to 98.7 billion USD.

Last year, global meat production increased by a total of $1.25 \%$ up to 323 million tons, according to the latest world market report published by the Organization for Economic Cooperation and Development (OECD) and the Food and Agriculture Organization of the United Nations (FAO) [24].

The main countries that contributed to the development of the meat industry were the United States, China, Argentina, India, Mexico, Russia and Turkey [25].

In the near future, analysts expect a slight decrease in meat prices due to an increase in meat supplies, which is associated with an increase in livestock, which is observed in some countries.

In 2027 , world meat production is forecasted to be $15 \%$ higher relative to the base period. Poultry remains the main growth factor in a total meat production volume, but in the next decade, growth in poultry meat production will slow down significantly compared to the previous one.

For example, in order to prevent these forecasts from coming true, China launched the innovative project by means of China's biggest online retailer JD. The project called Runnuing Chicken is aimed at help to poor people through online trading. The main 
purpose of the project is to provide financial assistance to families registered as poor and having loans. Those families, through an online order, get chickens for free-range breeding. The period of natural growth of each chicken is registered and after four months of feeding the bird is sold on the market. The project includes intelligent monitoring, mass slaughter, processing, transportation and other parts of the production chain. The final stage of the project is the supply of high-quality poultry meat to consumers.

Thus, the Running Chicken project not only helps low-income families climb out of poverty, but also represents JD.com as an enterprise that bears social responsibility and adheres to the concept of a quality life.

More and more people believe that "there is no outside observer in helping the poor," the number of people wishing to help the state in combating poverty through the purchase of products from poor areas is growing. The project proved that the production of healthy food, the creation of well-known brands in agriculture, and assistance to poor families all these measures are showing a good result. JD networks next step planned is to expand Running Chicken to Jiangsu, Hebei and Guizhou Provinces under the leadership of the PRC State Council's bureau of support to people in need, and then to launch other support projects for those in need, for example, a project on growing and selling ducks, etc. They will cover even more poor families and create a new model of helping the poor in the entire industry chain.

According to estimations of analysts, over the next decade the increase in the global demand for animal proteins is expected to slow down in terms of poultry and pork and increase in terms of beef and mutton. Brazil and the United States will cover $47 \%$ of the global market share, helping with nearly two-thirds of expected growth in global meat exports during the forecast period. World trade will continue depending on factors such as outbreaks of animal diseases, sanitary restrictions and trade policies, as well as consumer preferences and attitudes towards meat consumption in general. According to FAO forecasts, in the next 10 years, beef and mutton will gain popularity in the world market.

\section{Conclusions}

After completing the analysis of the global meat market, it can be stated that international demand for beef surpasses the global supply: it is expected that high demand in Asia will incentivize the growth of prices for imported beef. Next year, global beef production is expected to grow by $1 \%$, with the maximum growth taking place in South America and the USA.

FAO gives a forecast that over the next 10 years, beef and mutton will gain popularity in the global market. The United States, along with China, Argentina, India, Mexico, Russia and Turkey, have made the major contribution to this development. In the near future, analysts expect a slight decrease in prices for meat due to the increase in meat supplies, which is entailed by the increase in cattle stock observed in some countries. World meat production is forecasted to be $15 \%$ higher in 2027 if comparing to the base period. Poultry remains the main growth factor in total meat production, but in the next decade, growth in poultry meat production will slow significantly compared to the previous decade. Analysts expect that the growth of global demand for animal proteins over the next decade is going to slow down in terms of poultry and pork and to increase in terms of beef and mutton. Brazil and the United States will cover $47 \%$ of the global market, contributing to nearly two-thirds of expected growth in global meat exports during the forecast period. World trade will remain depending on such factors as outbreaks of animal diseases, sanitary restrictions and trade policies, as well as on consumer preferences and attitudes to meat consumption in general. 
Thus, only measures of state support for the industry will allow improving the quality of meat products, as well as contributing to the effectiveness of the implementation of programs aimed at increasing the development and introduction of new technologies that will increase the volume of production and consumption of agricultural products.

Development of the industry of cattle breeding, poultry farming, pedigree work, as well as increase in the number of processing complexes will surely allow solving the problem of ensuring food security, which for today is the most important task for the population of our planet.

\section{References}

1. N.I. Semenova, S.P. Utyatskiy, Nauchno-metodicheskiy elektronnyy zhurnal "Kontsept" 23, 76-80 (2015) http://e-koncept.ru/2015/95260.htm.

2. A.I. Altukhov, Prikladnyye ekonomicheskiye issledovaniya 5(9), 4-12 (2015)

3. A.I. Altukhov, Razvitiye prodovol'stvennogo rynka Rossii (Agri-Press, M., 2015)

4. S.S. Dzasarov, Voprosy ekonomicheskoy bezopasnosti 8, 23 (2015)

5. I. Ivolga, V. Timofeeva, Vestnik APK Stavropol'ya S1, 70-73 (2014)

6. A.I. Altukhov, APK: ekonomika, upravleniye 2, 19 - 29 (2014)

7. E. Ganebnykh, T. Burtseva, A. Petuhova, A. Mottaeva, E3S Web of Conferences 91, 08035 (2019) doi.org/10.1051/e3sconf /20199108035

8. A. Mottaeva, MATEC Web of Conferences 193, 05039 https://doi.org/10.1051/matecconf/201819305039

9. O.A. Donskova, Ekonomika i predprinimatel'stvo 10, 385 - 388 (2014)

10. N. Tulebayeva, D. Yergobek, G. Pestunova, A. Mottaeva, Z. Sapakova, E3S Web of Conferences 159, 01012 (2020) https://doi.org/10.1051/e3sconf/202015901012

11. M.V. Klinova, Ye.A. Sidorova, Voprosy ekonomiki 12, 67 - 79 (2014)

12. L.A. Kopteva, L.V. Shabalina, Finansovaya ekonomika 4(1), 59 - 61 (2018)

13. L. Kopteva, L. Shabalina, A. Prorokov, MATEC Web Conf. International Science Conference SPbWOSCE - 2017 «Business Technologies for Sustainable Urban Development» 170 (2018) https://doi.org/10.1051/matecconf/201817001054

14. L. Kopteva, L. Shabalina, E. Kashirina, E3S Web of Conferences 91, 06011 (2019) https://doi.org/10.1051/e3sconf/20199106011

15. L.A. Kopteva, L.V. Shabalina, N.G. Lashkova, Finansovaya ekonomika 10, 45 - 51 (2019)

16. L. Akhmetshina, A. Sergeev, A. Mottaeva, E3S Web of Conferences 91,06008 (2019) https://doi.org/10.1051/e3sconf /20199106008

17. N.T. Nazarenko, S.A. Gorlanov, Sel'skokhozyaystvennyye rynki: Kratkiy kurs lektsiy (VGAU, Voronezh, 2003)

18. G.A.

Yastrebinskaya,

KiberLeninka, http://cyberleninka.ru/article/n/prodovolstvennaya-bezopasnost-ekonomika-i-ekologiya

19. V.G. Larionov, Prodovol'stvennaya politika i bezopasnost' 2(1), 47-58 (2015)

20. I.N. Krutova, O.I. Yeremina, Gosudarstvennaya finansovaya podderzhka agrarnogo sektora ekonomiki (Natsional'nyy issledovatel'skiy Mordovskiy gosudarstvennyy universitet im. N.P. Ogareva, Saransk, 2015)

21. Obzor rynka sel'skogo khozyaystva. Issledovatel'skiy tsentr «Deloyt» (2018) http://https://www2.deloitte.com/ 
22. D. Rikardo, Sochineniya T.3. Stat'i po agrarnomu voprosu i kriticheskiye zamechaniya k knige Mal'tusa (Gosudarstvennoye izdatel'stvo politicheskoy literatury, M., 2016)

23. T.V. Bychkova, Agrarnaya nauka 2, 7-12 (2016)

24. R.R. Galiyev, Rossiyskiy elektronnyy nauchnyy zhurnal 1, 42-63 (2013)

25. V.Y. Sidorova, Povysheniye konkurentosposobnosti zhivotnovodstva i zadachi kadrovogo obespecheniya, 34-39 (2019) 